\title{
TECHNOLOGY MANAGEMENT IN GENETICS
}

\author{
Hatairuk Tungkasen \\ Department of Biology, \\ Faculty of Science and Technology, \\ Bansomdejchaopraya Rajabhat University \\ (Email: Thatairuk@gmail.com)
}

Accepted date: 01-09-2018

Published date: 09-07-2019

To cite this document: Tungkasen, H. (2019). Technology Management in Genetics. Journal of Information System and Technology Management, 4(13), 27-31.

DOI: $10.35631 /$ JSTM.413003

\begin{abstract}
Technology management in genetics course utilizes laboratory techniques and instrumentation to study the genetics involves the molecular genetics such as DNA, RNA or protein. Specifically, the variety of technologies methods to suit different learning styles including media or video bring benefits and the knowledge base is important to develop the learner. This research has been shown the technology of genetics to teach and learning for science by using videos, demonstrations and the journal of protein analysis which is SDS-PAGE technique used. Result shown the technologies management method is good to be applied for students in the course of genetics. After the student watched media, video and demonstrations the SDS-PAGE technique they can use the SDS-PAGE to analysis the proteins. The result has shown that the protein patterns from different follicle sizes. The porcine follicles ranged from 1-2 and 3-4 millimeters (mm.) follicles. As a result, showed protein patterns composed of 18 to $\geq 220 \mathrm{kDa}$ which were found in follicle samples from all sizes. Moreover, the notification of the porcine follicles in diameter of 3-4 mm. has been found the protein bands at 100 and $120 \mathrm{kDa}$, in accordance to a study by Miyamoto et al., 1985 which report $100 \mathrm{kDa}$ was Inhibin. The study of Nagyova in 2004 found that the protein band of $120 \mathrm{kDa}$ was inter alpha trypsin inhibitor family. The information of proteins can collect in to computer system which is able to use to develop technology genetics applications for protein studies. This research shows that technologies' management will support and have benefits for the learners. They can improve their learning and scientific skills. In the other hands, the development of new instruction media and teaching techniques are important and necessary for continuing works through the scientific process systematically.
\end{abstract}

Keywords: Multimedia Technology; Learning Management; Sodium Dodecyl SulfatePolyacrylamide Gel Electrophoresis (SDS-PAGE)

\section{Introduction}

Genetic technology is the genetic testing. This involves tests that identify which variant of DNA, RNA or protein. They have a variety of uses, including diagnosing rare diseases and 
commercial services that provide you with medical information or family history. This research study a variety of technology management in genetics by use media, video, demonstrations and the journal of protein analysis which is Sodium dodecyl sulfatepolyacrylamide gel electrophoresis (SDS-PAGE) technique for student that genetics course. The SDS-PAGE is a technique performed a variant of polyacrylamide gel electrophoresis, an analytical method for the separation of the molecular masses in an electric field. We studied protein from follicular fluid of the organ of pig that do not use such as ovaries. The ovaries of animal such as porcine have secreted sex hormones such as estrogen, progesterone for developing of the ovulation (Stankiewicz, T., 2015). The ovaries fall out of the ovary when ovulation. The ovarian structure consists of two layers; the first layer is cortex consisted of follicles, which is the outer layer of the ovary surrounds the ovaries. The second layer is medulla composed of fibroblastic connective tissues. When the animal enters the reproductive age (puberty), which causes the cells to develop to maturity, the ovaries are matured into the maturation oocytes. Each of the follicles contained one ovary; after the follicle develops it will be grown. Follicular fluid markers of oocyte development. (Fu, Q., et al. 2015, Revelli, A., et al. 2009 and Mendoza, C., et al. 2002). The follicular fluid and cumulus cells are influence of oocyte quality (Da Broi, M. G., et al. 2018). The pigs are the one of major economic animals in Thailand and popular for consumption. Nakhon Pathom is a province near to Bangkok and has a lot of pig slaughterhouses. The pigs have reproductive organs such as ovaries that cannot be consumed or utilized otherwise. The researchers decided to use this organ of animals for learning the components and functions of the reproductive system. The objective of this research is aimed for study the technology management in genetics use media, video, demonstrations and the journal of protein analysis which is SDS-PAGE technique for the students after they watched this technology teaching method they can analysis protein of the follicular fluid from the porcine follicular fluid (pFF) protein patterns by SDS-PAGE. The researcher studied the pattern of protein from the porcine follicles ranged from diameter of 1-2 and 3-4 millimeters (mm.) which the difference of porcine follicles will be appeared the molecular weight of various proteins. This is the basis for the protein found in any protein and may be used in the appropriate research.

\section{Materials and Methods}

\section{Porcine Ovaries Collection}

Porcine ovaries were collected from slaughterhouse in Nakorn Pathom province and transported to the laboratory within 1 hour at approximately $30-35{ }^{\circ} \mathrm{C}$ in $0.9 \%(\mathrm{w} / \mathrm{v})$ saline solution supplemented with $100 \mathrm{IU} / \mathrm{ml}$ penicillin, $100 \mu \mathrm{g} / \mathrm{ml}$ streptomycin and $250 \mu \mathrm{g} / \mathrm{mL}$ amphotericin B. The porcine cumulus-oocyte complexes (pCOCs) were collected from different follicles sizes. The follicles were individually punctured with an 18-G needle attached to a 5-ml syringe in a sterile petri dish. Recovered pCOCs were washed three times in $0.9 \%(\mathrm{w} / \mathrm{v})$ saline solution supplemented with antibiotics. The follicles were classified into 2 groups; $1-2 \mathrm{~mm}$. and 3-4 $\mathrm{mm}$.

\section{Porcine Follicular Fluid Analysis}

Porcine follicular fluid was from different follicle sizes 1-2 $\mathrm{mm}$. and 3-4 $\mathrm{mm}$. The follicular fluid of oocytes was determined for the total protein concentration by Lowry method (1951). The absorbance was measured at $750 \mathrm{~nm}$ and the protein concentration was estimated by comparing with protein standards. The SDS-PAGE is called for sodium dodecyl sulfate polyacrylamide gel electrophoresis, an analytical method for the separation of the molecular masses in an electric field. This learning management is good to be applied for students in the course of Genetics. The students studied in the classroom and analyzed the porcine follicular 
fluid $(\mathrm{pFF})$ protein patterns by SDS-PAGE. The protein was separated by using XCellSureLock $^{\mathrm{TM}}$ Mini-Cell Electrophoresis System. $20 \mu \mathrm{g}$ of proteins samples were electrophoresed on 4-12\% Bis-Tris gel (NuPAGE® gel) in MES-SDS running buffer at 200 volts for $50 \mathrm{~min}$. The gel was washed with distilled water and stained in Simplyblue (Invitrogen).

\section{Results}

\section{Porcine Follicular Fluid Protein Pattern Analysis}

The protein patterns of porcine follicular fluid were determined by SDS-PAGE using 4-12\% Bis-Tris gel in MES-SDS running buffer at 200 volts for $50 \mathrm{~min}$. The gel was washed with distilled water and stained in Simply blue. The protein bands were resolved the ranging in size from 18, 23, 55-60, 68, 90, 130, 150-160, 200, 205 and $\geq 220 \mathrm{kDa}$ which were found in follicle samples from all sizes. Moreover, the notification of the porcine follicles in diameter of 3-4 $\mathrm{mm}$. found the protein bands at 100 and $120 \mathrm{kDa}$ (Figure 1).

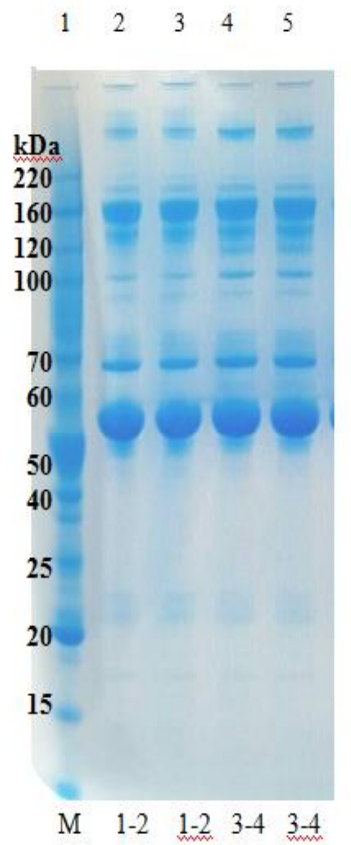

Figure 1: Protein Profile of Porcine Follicular Fluid, The Proteins Were Separated Using Nupage®Gel (4-12\% Bis-Tris) in MES-SDS Running Buffer. Lanes 1 Marker, Lanes 2 And 3 Are 1-2 mm., Lanes 4 And 5 Are 3-4 mm. Follicles.

\section{Conclusion}

This study brought the ovaries of female pigs collected from slaughterhouses in Nakhon Pathom province. After the students watched the variety of technology the students tested the molecular weight of protein that is unknown in different sizes of the porcine follicles of protein analysis by using the Sodium dodecyl sulfate Sodium dodecyl sulfate polyacrylamide gel electrophoresis (SDS-PAGE). The proteins are separated in polyacrylamide gel based on the difference of their molecular weight. The porcine follicles ranged from diameter of 1-2 and 3-4 millimeters (mm.). The results of both porcine follicles showed that protein band size composed of 18, 23, 55-60, 68, 90, 130, 150-160, 200, 205, and more than 220 Kilo Dalton $(\mathrm{kDa})$. The findings are consistent with many the reports and studies. The study of Castilla et al., in 2010 shown the analysis of secretion proteins of porcine oocytes by SDS-PAGE and 
suggested that protein band at $23 \mathrm{kDa}$ was Vasoinhibin. The vasoinhibin is a component of prolactin, which is produced by the pituitary gland. It controls the creation or secretion of milk. This hormone is higher during pregnancy and lactation. Prolactin also stimulates the growth of endothelial cells and angiogenesis. The study of Miyamoto et al., 1985 found thatprotein band at $55 \mathrm{kDa}$ was Inhibin. In 2001, Findlay et al., reported that Inhibin had a level of change in the development of follicular. A study of Ducolomb et al., in 2013 explained that protein band at $160 \mathrm{kDa}$ was Transthyretin or prealbumin is responsible for transporting thyroid hormones from the thyroid gland. To support a study by Wanna., 2009 found protein band at more than $220 \mathrm{kDa}$ was Fibronectin or Keratin. The fibronectin is binding with cell surface, collagen, fibrin, glycosaminoglycan or heparin that can be regulated the physiological balance of the cells such as phagocytosis and wound repair. Whereas the porcine follicles in diameter of 3-4 mm. found the protein bands at 100 and 120 $\mathrm{kDa}$, according to a study by Miyamoto et al., in 1985 reported that $100 \mathrm{kDa}$ was Inhibin.

While, Rivier et al., in 1985 studied purification and partial characterization of inhibin from porcine follicular fluid that suggesting a molecular weight of $32 \mathrm{kDA}$ for inhibin. As same as the reported that Cottom et al., in 2003 the protein with a molecular weight of $100 \mathrm{kDa}$ was stimulating the follicle-stimulating hormone (FSH) in female, which stimulates ovarian growth and stimulates the ovaries to produce estrogen, while, the male sex stimulates sperm production. The studied of Nagyova in 2004 and Nagyova et al., in 2018 found that the protein band of $120 \mathrm{kDa}$ was inter alpha trypsin inhibitor family. The control of the follicular fluid in cumulus cells is possible for hyaluronic function. The studied of Yokoo et al., in 2011 reported that hyaluronic is revealed the apoptosis, cell adhesion, cell proliferation and development of cells. The expansion of cumulus cells is due to the synthesis and accumulation of hyaluronic around cumulus cells, too. After the student watched media, video, demonstrations and the journal of protein analysis they can analysis the protein by SDS-PAGE. Hence, the results of this study shown that the technologies management in genetics is useful for teaching and learning management system. Moreover, the data from molecular weight of proteins was basic information that can be used to develop biotechnology applications for protein studies. This knowledge led to improve a genetic technology are being applied to diagnose disease of protein and develop more targeted drug treatments.

\section{References}

Castilla, A., García, C., Cruz-Soto, M., Martínez de la Escalera, G., Thebault, S., \&Clapp, C. (2010). Prolactin in Ovarian Follicular Fluid Stimulates Endothelial Cell Proliferation. $J$ Vasc Res, (47), 45-53.

Cottom, J., Salvador, L. M., Maizels, E. T., Reierstad, S., Park, Y., Carr, D. W., Davare, M. A., Hell, J. W., Palmer, S. S., Dent, P., Kawakatsu, i. H., Ogata, M. \& HunzickerDunna, M. (2003). Follicle-stimulating Hormone Activates Extracellular Signalregulated Kinase but Not Extracellular Signal-regulated Kinase Kinase through a 100kDa Phosphotyrosine Phosphatase. J Biol Chem, 278(9), 7167-7179.

Da Broi, M. G., Giorgi, V. S. I., Wang, F., Keefe, D. L., Albertini, D. and Navarro, P. A. (2018). Influence of follicular fluid and cumulus cells on oocyte quality: clinical implications. J Assist Reprod Genet. 35(5), 735-751.

Ducolomb, Y., Gonzalez-Marquez, H., Fierro, R., Jimenez, I., Casas, E., Flores, D., \& Betancourt, M. (2013). Effect of porcine follicular fluid proteins and peptides on oocyte maturation and their subsequent effect on in vitro fertilization. Theriogenology, 79(6), 896-904. 
Findlay, J. K., Drummond, A. E., Dyson, M., Baillie, A. J., Robertson, D. M., \& Ethier, J. F. (2001). Production and actions of inhibin and activin during folliculogenesis in the rat. Molecular and Cellular Endocrinology, (180), 139-144.

Fu, Q., Huang, Y., Wang, Z., Chen, F., Huang, D., Lu, Y., Liang, X., Zhang, M. (2016). Proteome Profile and Quantitative Proteomic Analysis of Buffalo (Bubalusbubalis) Follicular Fluidduring Follicle Development. Int J Mol Sci. 17(5), 618.

Kim, Y.S., Kim, M.S., Lee, S.H., Choi, B.C., Lim, J.M., Cha, K.Y., et al. (2006). Proteomic analysis of recurrent spontaneous abortion: identification of an inadequately expressed set of proteins in human follicular fluid. Proteomics. 6, 3445-3454

Mendoza, C., Ruiz-Requena, E., Ortega, E., Cremades, N., Martinez, F., Bernabeu, R., et al. (2002). Follicular fluid markers of oocyte developmental potential. Hum Reprod, 17, 1017-1022.

Miyamoto, K., Hasegawa, Y., Fukuda, M., Nomura, M., Igarashi, M., Kangawa, K. \&Matsuo, H. (1985). Isolation of porcine follicular fluid inhibin of 32K Daltons. Biochem Biophys Res Commun, 129(2), 396-403.

Nagyova, E., Camaioni, A., Prochazka, R., \& Salustr, A. (2004). Covalent Transfer of Heavy Chains of Inter-a-Trypsin Inhibitor Family Proteins to Hyaluronan in In Vivo and In Vitro Expanded Porcine Oocyte-Cumulus Complexes1. Biology of reproduction, (71), $1838-1843$.

Nagyova, E. (2018). The Biological Role of Hyaluronan-Rich Oocyte-Cumulus Extracellular Matrix in Female Reproduction. Int. J. Mol. Sci., 19(283), 1-14.

Revelli, A., $\quad$ Delle $\quad$ Piane, L., $\quad$ Casano, S., Molinari, E., Massobrio, M., Rinaudo, $\quad$ P. (2009). Follicular fluid content and oocyte quality: from single biochemical markers to metabolomics. Reprod Biol Endocrinol. 7, 40.

Rivier J, Spiess J, McClintock R, Vaughan J, Vale W. (1985). Purification and partial characterization of inhibin from porcine follicular fluid. Biochem Biophys Res Commun. 27, 133(1): 120-127.

Stankiewicz, T. (2015). Biochemical composition of the fluid of ovarian cysts and preovulatory follicles compared to the serum in sows. Tierarztl Prax Ausg G Grosstiere Nutztiere. 43(4): 216-221.

Wanna, M., (2009). Cell and protein secretion from porcine oviduct and ovary in estrous cycle. 118.

Yokoo, M., \& Sato, E. (2011). Physiological function of hyaluronan in mammalian oocyte maturation. Reprod Med Biol, (10), 221-229. 